\title{
A COMPARATIVE STRUCTURAL ANALYSIS OF FOUR RADIOSONDE MODELS
}

\author{
Norbert Hegyi* (iD 0000-0002-4569-2675 \\ János Jósvai (iD 0000-0001-9417-5191 \\ Széchenyi István University, Department of Vehicle Manufacturing, \\ Egyetem tér 1, H-9026 Győr, Hungary \\ * hegyi.norbert@sze.hu
}

\begin{abstract}
In this study, we first performed a comprehensive structural analysis of four models of radiosondes (devices intended for use as the meteorological probe of a sounding balloon) manufactured by three different companies - Graw, Vaisala and Meteomodem. The radiosondes were disassembled for visual inspection and manual measurement, three-dimensional computed tomography images were taken of their inner structure, and the outer shapes of the radiosondes were scanned with a structured-light threedimensional scanner. The structural properties of the radiosondes thus identified were then compared to one other, based on which the Meteomodem M10 was ranked as the least harmful in a potential collision. Next, the Meteomodem M10 radiosonde was used in collision tests with a heavy target and with a pumpkin model, in order to evaluate the possible damage caused by and to the radiosonde in different types of collisions.
\end{abstract}

Keywords: radiosonde, unmanned free balloon, computed tomography measurement, collision test Type of the work: Research Article

\section{INTRODUCTION}

Sounding balloons, or weather balloons, are mostly light or medium, unmanned, free balloons, which carry instruments for measuring meteorological data. They are usually composed of 3 main parts: the balloon itself, the parachute, and the meteorological probe (the parachute sometimes not being present - as shown on Fig. 1).

The meteorological probe of a sounding balloon is generally a radiosonde: an instrument carried up to high altitudes of Earth's atmosphere to measure atmospheric parameters (e.g. air pressure, temperature, etc.), so as to transmit the measured data by radio back to Earth [1]. In the EU, unmanned free balloons are regulated by the Commission Implementing Regulation (EU) No. 923/2012, which defines certain characteristics for the categorization of light, medium and heavy unmanned free balloons. Relevant to this study are the mass and area density characteristics defined for light unmanned free balloons. Namely, a "light unmanned balloon" is defined by the regulation as having a payload of one or more packages with a combined mass of less than $4 \mathrm{~kg}$, not having any package of $3 \mathrm{~kg}$ or more; and not having a package of $2 \mathrm{~kg}$ or more with an area density greater than $13 \mathrm{~g} / \mathrm{cm}^{2}[2]$. 


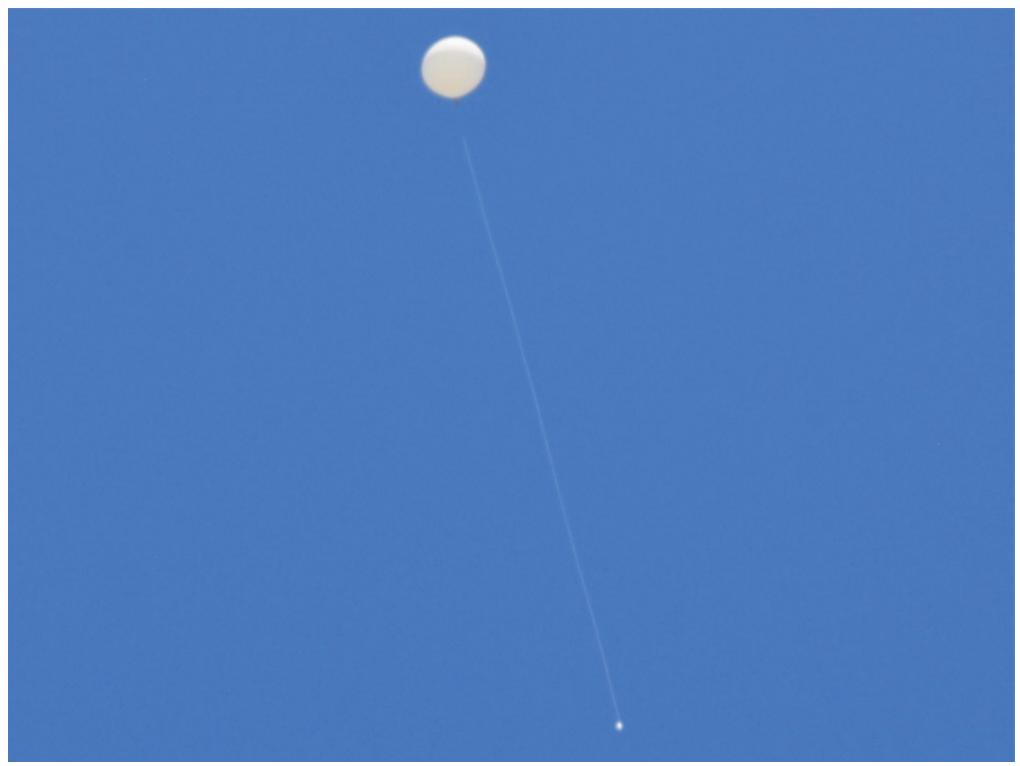

Fig. 1. A sounding balloon of the Hungarian Meteorological Service.

However, radiosondes come in numerous shapes and designs, produced and distributed by many different companies. In this study, we first structurally examined four radiosonde models in various ways, analyzing them and comparing them to one another. Based on these findings, we sought to identify which of the four models could be estimated to be the least harmful in a potential collision. Next, the radiosonde model so identified would be used in collision tests with a heavy target and with a pumpkin model, in order to evaluate the possible damage caused by, and caused to, the radiosonde in different collisions.

\section{RADIOSONDES}

In this study, we invested four radiosonde models, manufactured by three different producers: the DFM-09 model by Graw, the M10 model by Meteomodem, and the RS41 and RS92 models by Vaisala (shown in Fig. 2). Most of the radiosonde models also have different versions, which outwardly look identical but have different internal structures (e.g. different instruments, batteries of a different type, etc.).

In this section, we analyze these four devices in terms of their structural aspects, as examined visually, measured partially by digital caliper, and scanned by computed tomography. The inner parts were examined using normal visual photographic and computed tomography images. The 3D computed tomography models were taken with an Yxlon YCT modular and a flat panel Y.XRD1260 detector at the University of Györ, Hungary [3]. The outer shape of the radiosondes was scanned with a GOM ATOS Triple Scan 2 structured-light 3D scanner, also at the University of Györ [4]. The surface areas mentioned in the later parts of this article were calculated from the 3D scanned images with help of the GOM Inspect software [5][6]. 


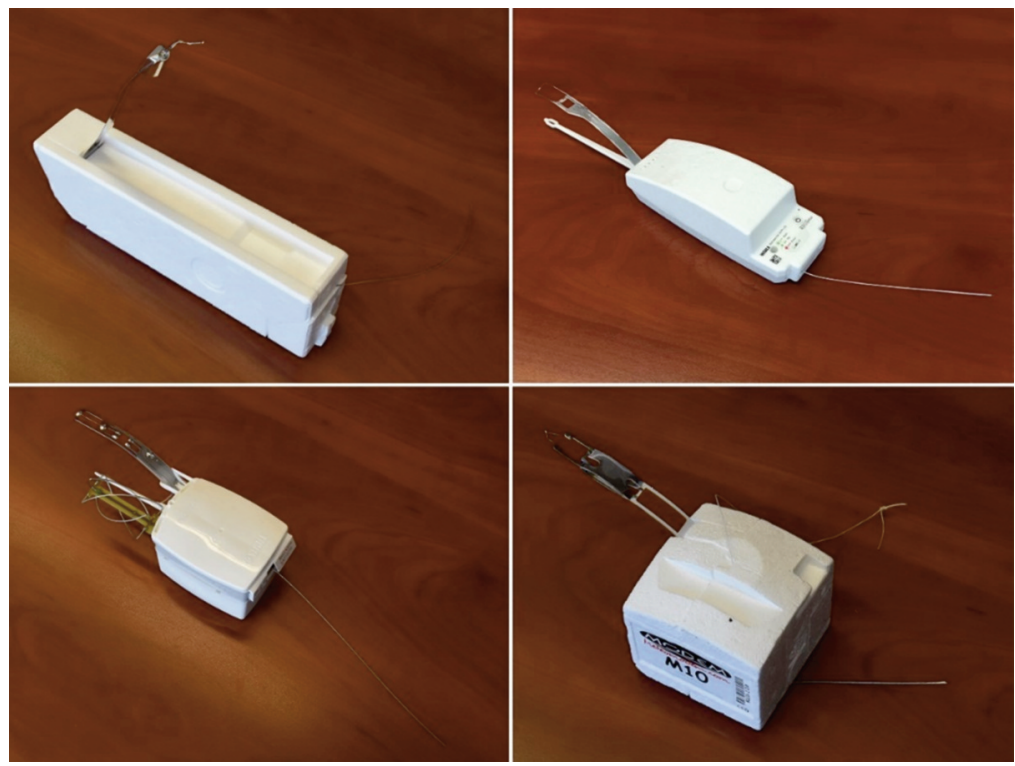

Fig. 2. The radiosondes examined in this study: the Graw DFM-09 (top left), the Vaisala RS41 (top right), Vaisala RS92 (bottom left), Meteomodem M10 (bottom right).

In each case, our examination considered the following aspects, which influence various properties of the given radiosonde:

- the form of the radiosonde,

- its size,

- the properties of its outstretching parts,

- the property of its material,

- the property of its cover,

- its inner structure,

- its mass,

- and its surface density.

The values identified for each aspect were used in later comparative analyzes.

\subsection{Graw Radiosondes DFM-09}

The radiosonde model shown in Fig. 3 has an outer case made of plastic with an extruded polystyrene (XPS) body inside. The purpose of the plastic case is to hold the radiosonde and connect it to the string under the balloon [7].

Fig. 3 shows the radiosonde still inside its plastic case, whereas the previous Fig. 2 shows the radiosonde taken out of the outer case. Contained inside the XPS itself are the internal electronics. On the body's upper portion, the meteorological sensors are connected from the side (left side of the image). Running downwards from the bottom of the radiosonde is a metallic colored wire, the antenna for measurement data transmission. The data-transmitting antenna and the flat part comprising the weather sensors are both bendable. 


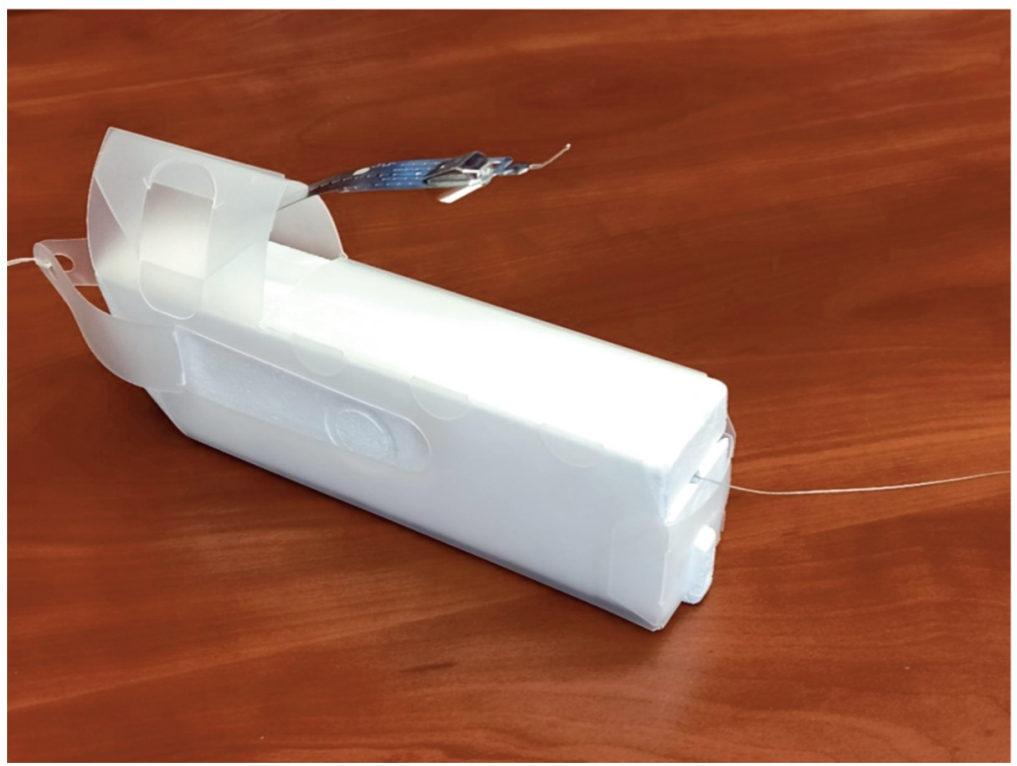

Fig. 3. The Graw Radiosonde DFM-09 inside its plastic case.

Fig. 4 shows the radiosonde once disassembled, with the internal electronics visible: two layers of printed circuit boards (PCB), with a global navigation satellite system receiver on the top. The twolayered PCB structure makes it less bendable compared to a one-layered structure. The device also has two $3 \mathrm{~V}$ electric CR123A batteries.

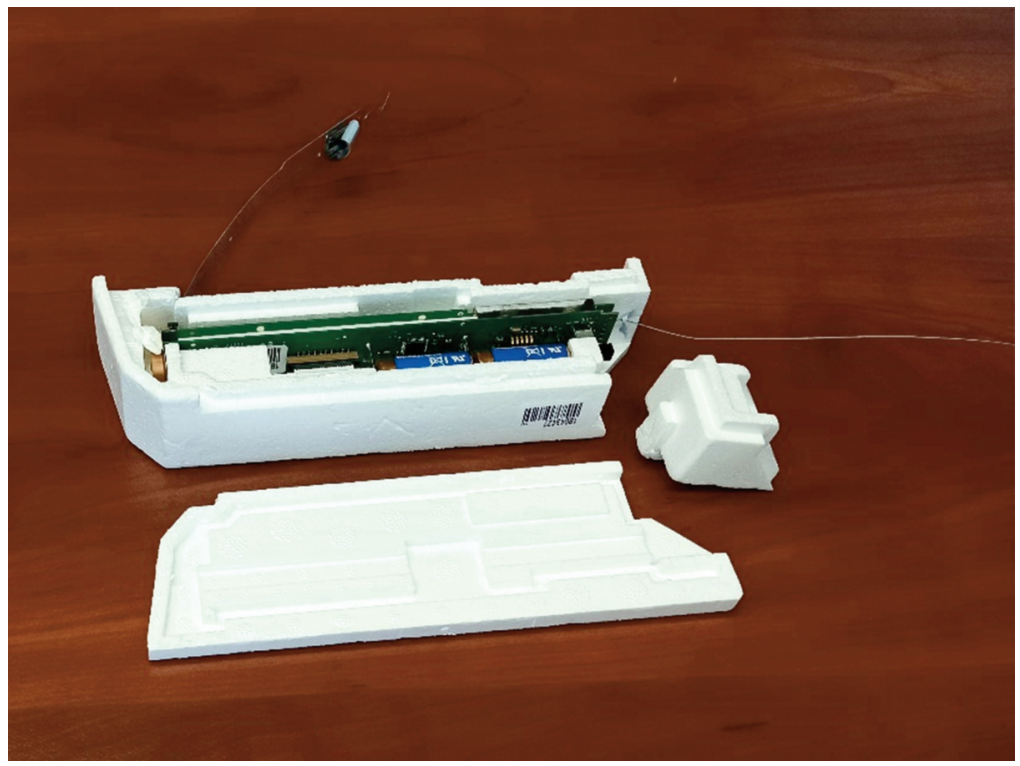

Fig. 4. The Graw radiosonde DFM-09 disassambled. 
Fig. 5. shows the inner parts of the radiosonde on a computed tomography image, which clearly shows the densest parts of the radiosonde as compared to the XPS parts. The global navigation satellite system sensor, the two layered printed circuit boards, the 2 CR123A $3 \mathrm{~V}$ batteries, the outer meteorological sensors and the data transmitting antenna are all shown.

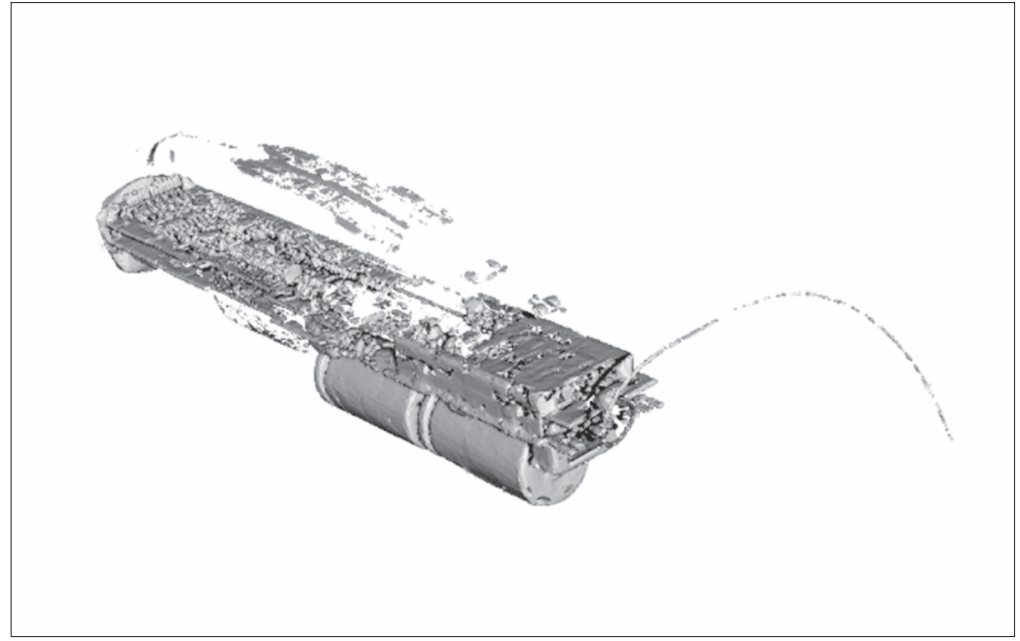

Fig. 5. The Graw Radiosonde DFM-09, computed tomography image.

The weight of this radiosonde is 85 grams without its plastic case. The measured dimensions (height $\times$ length $\times$ width) of the body are $200 \times 40 \times 60$ millimeters (without the plastic case, sensors and antenna). The antenna on the downside is $162 \mathrm{~mm}$ long outside the body. The smallest surface of the device is a $5 \mathrm{~mm}$ high, out-hanging part of the XPS body, with a size of $180 \mathrm{~mm}^{2}$. Calculated with $180 \mathrm{~mm}^{2}$ area, the area density is $55.55 \mathrm{~g} / \mathrm{cm}^{2}$. From another point of view, as this small area is just a part of a larger one, it can be considered as an out-hanging section of the larger area, so it is not the relevant size for the calculation. There is flat part with an area of $780 \mathrm{~mm}^{2}$, which can be seen as the smallest surface on the probe. Calculated with the more appropriate $780 \mathrm{~mm}^{2}$ the area density is $12.82 \mathrm{~g} / \mathrm{cm}^{2}$.

\subsection{Vaisala RS41-SG}

The RS41-SG, seen in Fig. 2, is a complete model, shown with its cuboid form. It has an outer body made of expanded polystyrene (EPS), but note that a version with a rigid plastic cover has also been produced [8]. The properties of the EPS body can be seen as positive: it insulates the instrument, is lightweight, and can also absorb force in a collision. As is visible in Fig. 2, on the downside of the radiosonde there is a metallic colored wire, which is the data transmitting antenna of the device. On the upper side there is a metallic grey colored flat part. It contains the air pressure, humidity and temperature sensors. On the upper side of the radiosonde, there is a long white plastic rod connected to the body, to be used to affix it for hanging under the balloon. The data transmitting antenna and the flat part of weather sensors are bendable, while the white plastic rod is partially flexible.

Fig. 6 shows the RS41-SG radiosonde when disassembled. The two larger white colored pieces are the outer body of the radiosonde. It does not have a cover layer on the body. The sensors, flat PCB, with the batteries and the transmitting antenna are in between the body parts.

In Fig. 7, the densest parts of the radiosonde can be seen on a computed tomography image. The parts shown are much denser than the EPS parts. The flat printed circuit boards, the $2 \mathrm{AA}$ sized $1.5 \mathrm{~V}$ lithium batteries, the outer meteorological sensors and the data transmitting antenna are shown. 


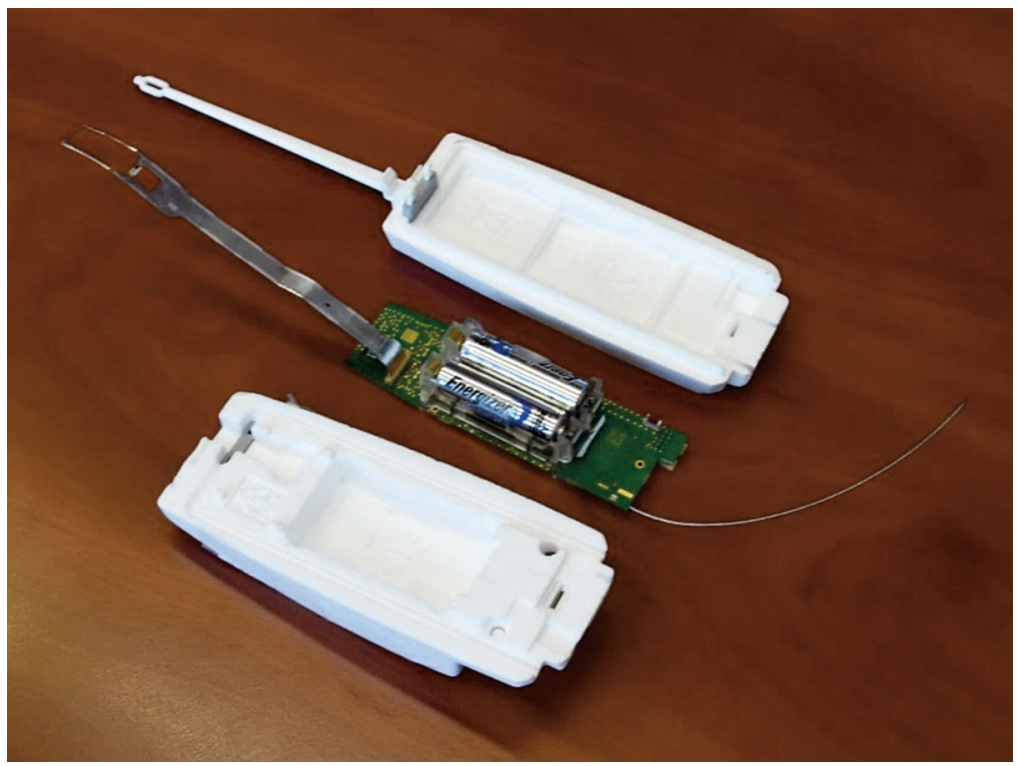

Fig. 6. The Vaisala RS41-SG disassambled.

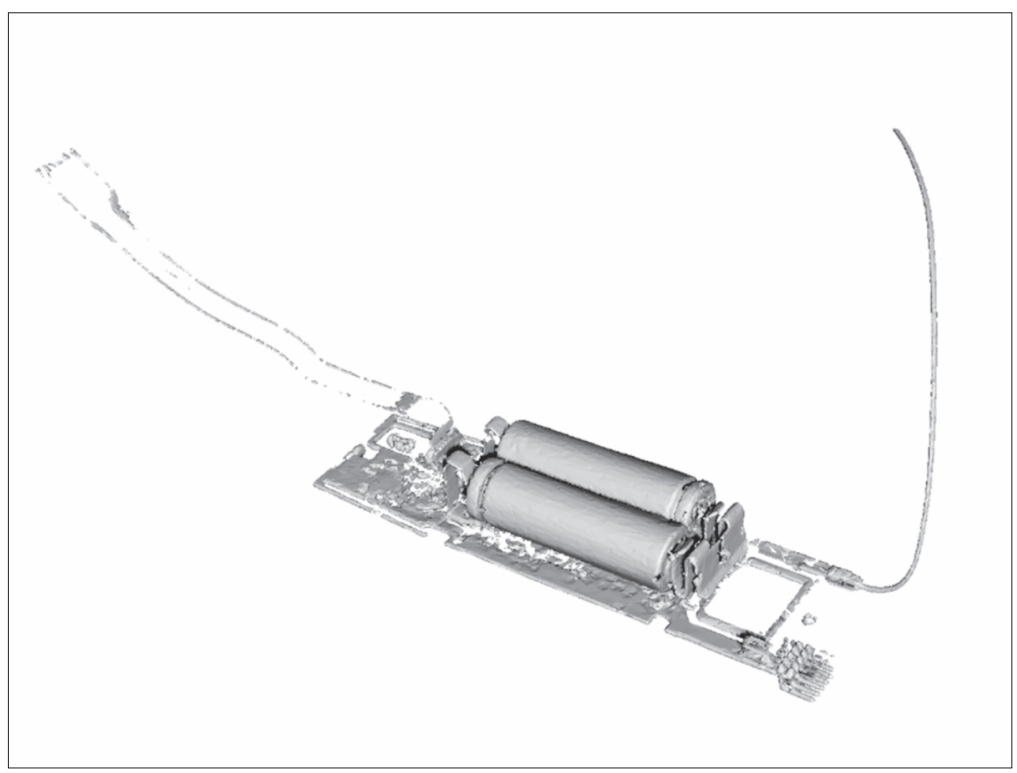

Fig. 7. The Vaisala RS-41-SG, computed tomography image.

The weight of the examined model is 80 grams. The measured dimensions (height $\times$ length $\times$ width) of the main body itself are $155 \times 46 \times 63$ millimeters. The dimensions (height $\times$ length $\times$ width) with the plastic rod are $282 \times 46 \times 63$ millimeters. These both the same as the factory given parameters. The rod is 130 millimeters, and the antenna outside the body 118 millimeters long. The smallest surface area of the radiosonde is $733 \mathrm{~mm}^{2}$, or $7.33 \mathrm{~cm}^{2}$ which means an area density of $10.91 \mathrm{~g} / \mathrm{cm}^{2}$. 


\subsection{Vaisala RS92}

The Vaisala RS92 is a radiosonde produced by the Finnish company Vaisala. The RS92 has three versions. Fig. 2 shows a complete RS92-SGPA model. It has an outer bodyshell made of high-density polyethylene; inside this outer layer is the inner body [9].

The radiosonde has on its downside a metallic colored wire which is the data transmitting antenna. On the upper side is a quadrifilar helix antenna (QHA) for receiving global positioning satellite system signals. Also on the upper side of the device is a metallic grey colored flat part, containing the air pressure, humidity and temperature sensors. There is also a long white plastic rod connected to the body, meant to be used to affix it for hanging under the balloon. The data transmitting antenna and the flat part of sensors are bendable, the white plastic rod is partially flexible. The QHA is made of metal and is dimensionally stable. The whole QHA - taken as one unit - can be bent a few degrees towards the front and back side of the radiosonde at its connection. The out-hanging size and its strength, as compared to the EPS and XPS or to the bendable weather sensors, can be seen as a negative property.

Fig. 8 shows a disassembled RS92. Under the plastic bodyshell is EPS for insulating purposes. The RS92-SGPA version shown has 6 AA alkaline batteries inside. It has two small liquid containing pieces for heat containing purposes, to prevent the batteries and electronic parts from undercooling at higher atmosphere. The outer bodyshell has properties which can be seen as negative. It is harder than EPS. It does not absorb pressure at collision, as an EPS bodyshell. This model's inner layers of EPS insulate the instrument.

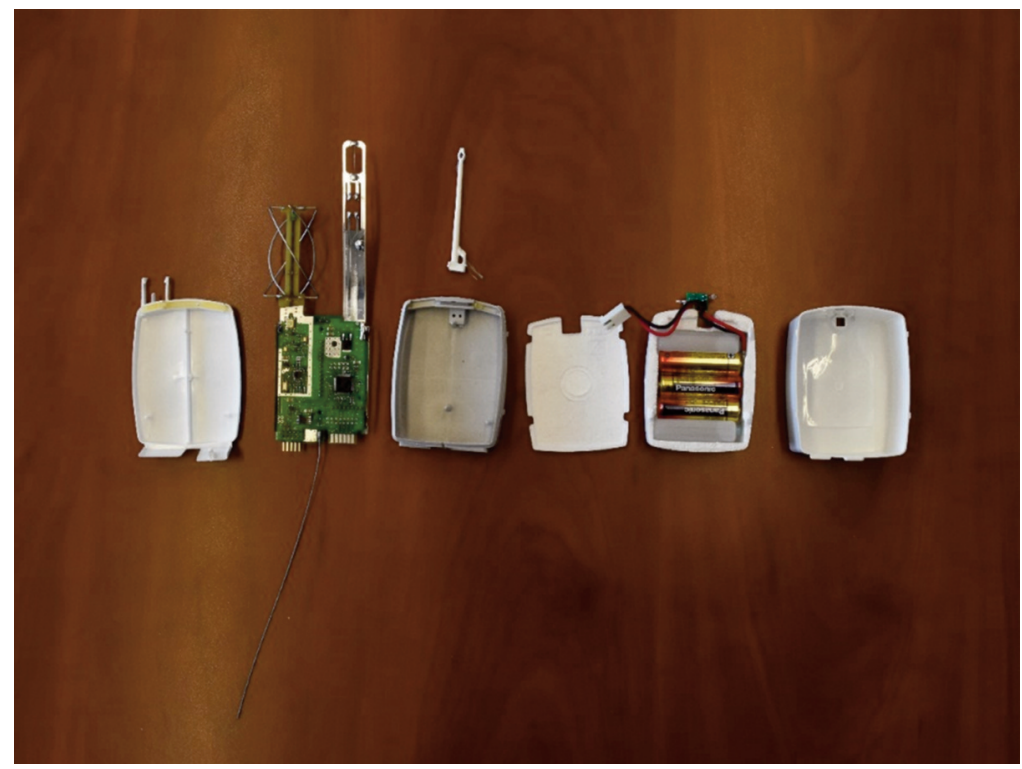

Fig. 8. The Vaisala RS92-SGPA disassembled.

On Fig. 9, the inner parts of the radiosonde can be seen on a computed tomography image. The densest parts the radiosonde can be seen in one piece on the 3D model. The multiple layers of printed circuit boards, the powering batteries, the outer QHA, meteorological sensors and the data transmitting antenna are shown. 
The weight of the examined model is 280 grams. The dimensions (height $\times$ length $\times$ width) of the main body in itself are $94 \times 73 \times 70 \times$ millimeters. The dimensions (height $\times$ length $\times$ width) with the plastic rod are $160 \times 75 \times 74$ millimeters. The rod is $75 \mathrm{~mm}$, the helix antenna (for global navigation satellite system) is $61 \mathrm{~mm}$, antenna outside the body is $178 \mathrm{~mm}$ long. The smallest free surface area of the radiosonde is $3480 \mathrm{~mm}^{2}$, or $34.8 \mathrm{~cm}^{2}$ which means an area density of $8.19 \mathrm{~g} / \mathrm{cm}^{2}$.

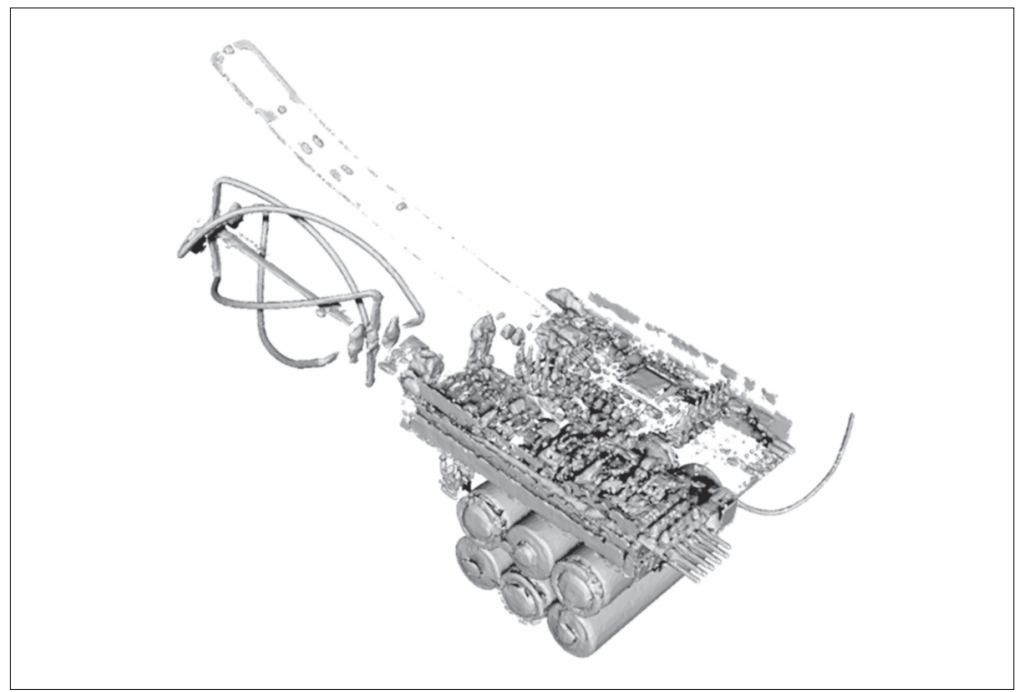

Fig. 9. The Vaisala RS92-SGPA, computed tomography image.

\subsection{Meteomodem M10}

The M10 type radiosonde is one the models produced by the company Meteomodem. It can be seen on Fig. 2. with a white colored body made of EPS [10].

Its body is light, insulating, and can absorb dynamic pressure. On the downside of the device there is a metallic colored wire functioning as the radio transmitting antenna. On the upper side, a flat metallic part can be seen, containing the sensors for measuring temperature, humidity and air pressure. At the upper center of the radiosonde there is a string for affixing it to a balloon in flight. The flat sensor part and antenna are flexible, bendable.

Fig. 10. shows a disassembled radiosonde, with its body cover taken off. The battery pack with 4 batteries is connected to the electronics with a red and a black wire. The inner part is made of partially printed electronic circuits.

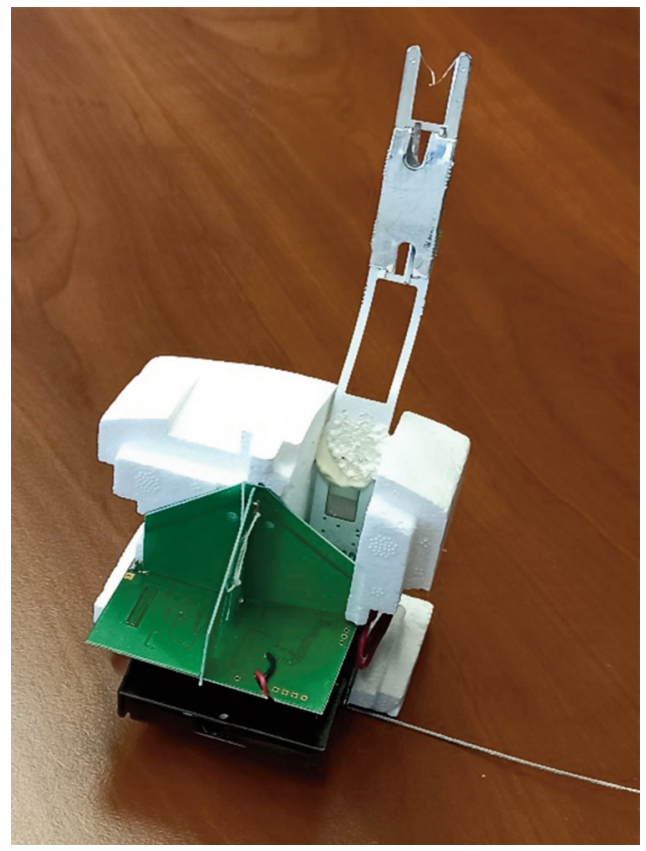

Fig. 10. The Meteomodem M10 disassembled. 
In Fig. 11, the inner parts of the radiosonde can be seen on a computed tomography image. The outer sensors, PCB, the 4 inserted batteries and the antennas are shown. The double $\Lambda$-form shown in the upper center of the radioprobe is the radiosonde's inner antenna for global positioning.

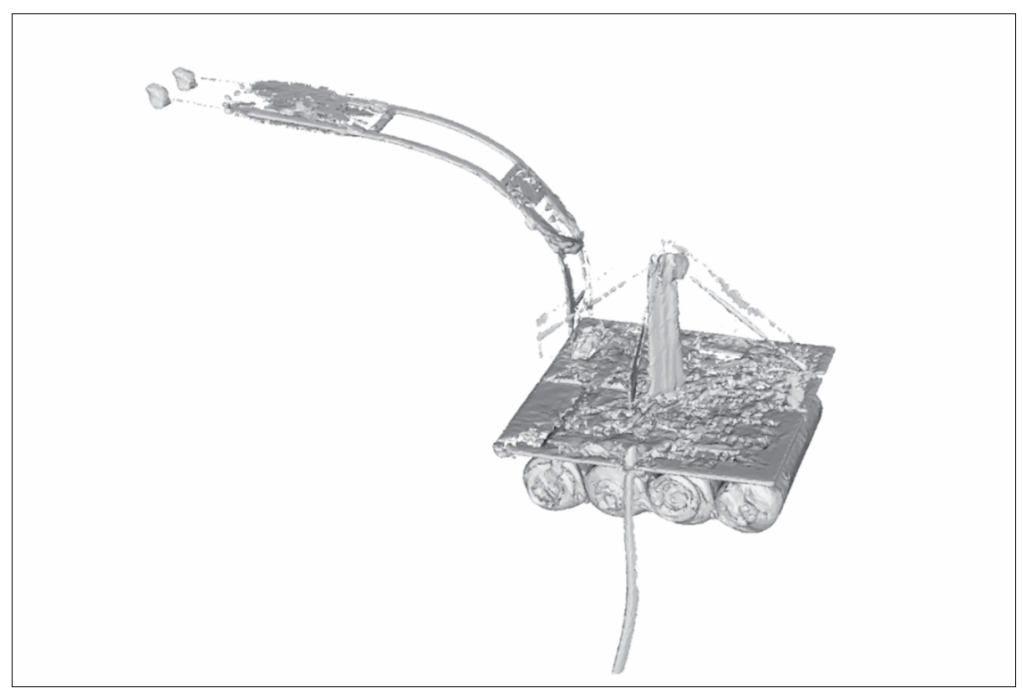

Fig. 11. The Meteomodem M10, computed tomography image.

The weight of this model is 150 grams. The measured dimensions (length $\times$ width $\times$ height) of the main body in itself are $94 \times 94 \times 88$ millimeters. The $1 \mathrm{~mm}$ difference between the factory given $95 \mathrm{~mm}$ and the measured size can be explained easy by the lack of the 2 rubber bands [8] usually used for giving extra convergence between the parts of the body. The length of the antenna outside the body is $148 \mathrm{~mm}$. The smallest surface area of the radiosonde is $7268 \mathrm{~mm}^{2}$, or $72.68 \mathrm{~cm}^{2}$ which means an area density of $2.06 \mathrm{~g} / \mathrm{cm}^{2}$.

\section{RATING OF RADIOSONDES}

The previous section examined and analyzed the four radiosondes in terms of their structural aspects. Next, a weighted rating was performed, yielding relative comparisons for each device. Aspects where the devices exhibited the same evaluations were omitted.

For the rating, the following aspects are used:

A. The material of the main body's outer layer: the properties of the radiosonde's outer shell and the material of the body. Value: 1-3 (best-worst)

B. Out-hanging parts: plastic rods and other (not light deformable) parts hanging out or protruding from the main body (note that the data transmitting antenna is not considered an out-hanging part in this rating). Value: 1-4 (1: no out-hanging parts; 2: plastic rod; 4: plastic rod and other out-hanging parts)

C. Area density: mass and smallest area rate in grams per square centimeters. Value: 1-4 (lowest density - highest density) 
Table 1. Comparative rating of radiosondes.

\begin{tabular}{|l|c|c|c|c|}
\hline Type of radiosonde & $\begin{array}{c}\text { Material } \\
\text { of outer } \\
\text { layer }\end{array}$ & $\begin{array}{c}\text { Outstretching } \\
\text { parts }\end{array}$ & $\begin{array}{c}\text { Area } \\
\text { density }\end{array}$ & $\begin{array}{c}\text { Cumulative } \\
\text { value }\end{array}$ \\
\hline Graw DFM-09 & 2 & 1 & 4 & 7 \\
\hline Vaisala RS-41SG & 1 & 2 & 3 & 6 \\
\hline Vaisala RS-92SGPA & 3 & 4 & 2 & 9 \\
\hline Meteomodem M10 & 1 & 1 & 1 & 3 \\
\hline
\end{tabular}

Based on these results, it may be concluded that in the event of a potential collision, the most harmful of the four devices would be the Vaisala RS-92SGPA, while the least harmful would be the Meteomodem M10.

\section{COLLISION TESTS WITH METEOMODEM M10 RADIOSONDES}

\subsection{Collision with a steel block}

The analysis reported in the previous section estimated the Meteomodem M10 to be the least dangerous, least potentially damage-causing of the four radiosonde models considered. We next proceeded to test this particular device to identify what kind of damage may still be caused to and by the radiosonde itself in a possible collision.

This collision tests were performed using an original experimental collision-simulation setup, following a simple experimental concept. Firstly, the radiosonde needed to attain a defined speed for the collision with a target. The target for this test was chosen in terms of many aspects, the two main ones being that firstly, it should be larger than the radiosonde, and secondly, it should be redundant for the collision itself. This led to the choice of a steel block. It had a mass of $19.5 \mathrm{~kg}$, and a size of $320 \times$ $180 \times 50 \mathrm{~mm}$ (not totally symmetrical). The spring (for accelerating the radiosonde) and the rod with the plate on its end had a mass of $375 \mathrm{~g}$. The descending speed at ground of this kind of radiosonde is between $10-15 \mathrm{~m} / \mathrm{s}$ in the case of a bad parachute, or simply without a parachute. The minimal speed of $10 \mathrm{~m} / \mathrm{s}$ was chosen for simulating this situation. The collision device was constructed after calculating the spring force required for accelerating the radiosonde (and the rod with the plate itself). The calculations were performed in keeping with basic laws of physics, such as Hooke's law and Newton's laws. The setup used a special spring produced for air rifles, which was found to be the best solution. The experiment was recorded in a high-speed video format of $240 \mathrm{fps}$ and also at normal $50 \mathrm{fps}$ rate. The radiosonde was accelerated to a final speed of $10 \mathrm{~m} / \mathrm{s}$, which was reaffirmed by analyzing the motion on the video itself. The calculations and the experiment were found to match. The test was repeated 3 times. Fig. 12 shows a frame from one recording. After the collision, the ruptured radiosonde bounced back; the black line on the radiosonde is the result of its deformation and rupture. 


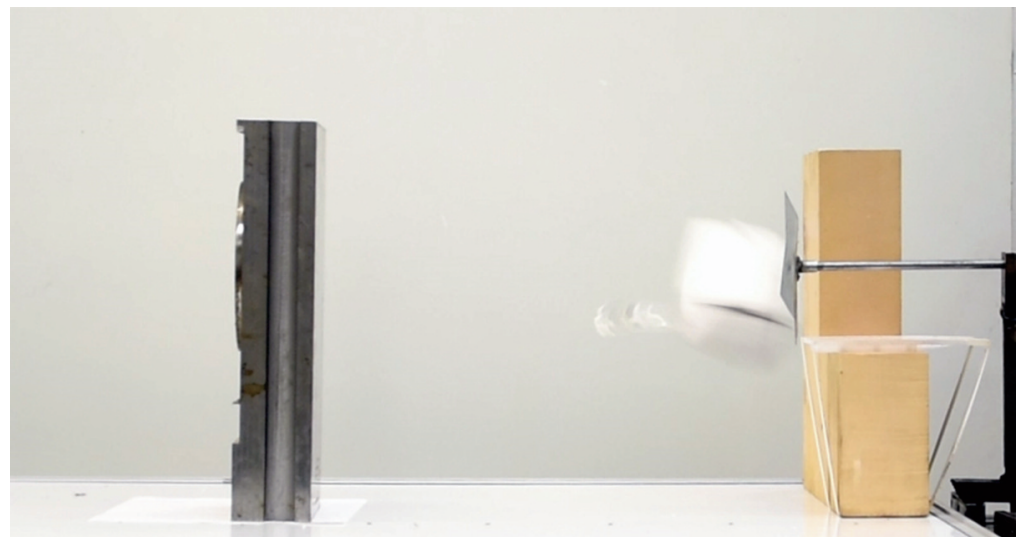

Fig. 12. Radiosonde bouncing off a steel obstacle, showing damage.

Each radiosonde was tested in collision just once. They were found to be damaged to varying degrees, even though the speed and distance were the same. As the radiosondes were acquired at various times, it is possible that the newer ones - only a few months old - may have been more resistant to damage. In Fig. 13, three different degrees of damage are shown. In the image on the left, the parts of the body have slightly slipped apart, with a minimal deformation of the downside of the radiosonde. In the middle image, the parts of the body have slipped apart more, with a crack visible in a main part, and deformation of the downside of the radiosonde. In the image on the right, the parts of the body have slipped apart, are broken and deformed. Half of the downside of the radiosonde is broken apart, half is deformed. The black battery insert case is outside the radiosonde, with just the two thin wires connecting it.
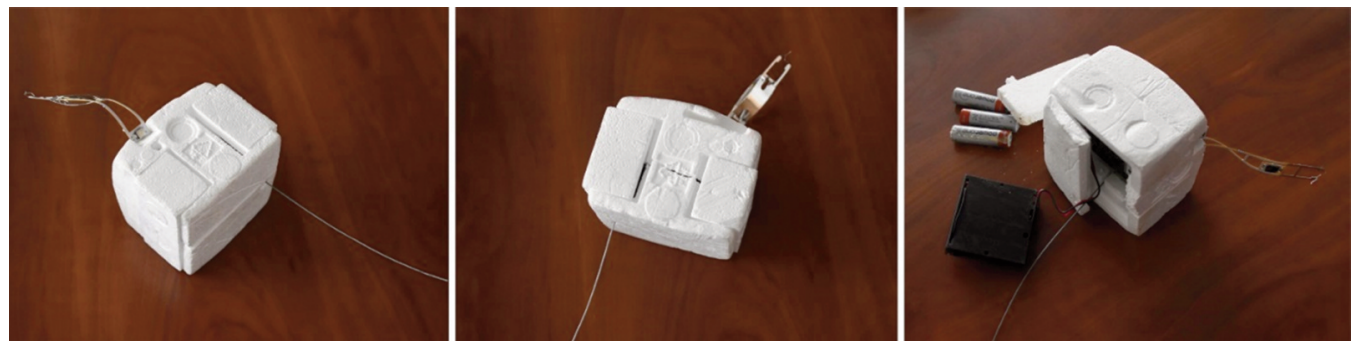

Fig. 13. Damaged radiosondes.

\subsection{Collision with a pumpkin}

The purpose of this test was to show the dangerous potential of a radiosonde collision. We searched the literature on the mechanical properties of vegetables to consider which might best serve as a model for a collision with a softer obstacle (e.g. a human being or animal). This review led us to choose a pumpkin as a model collision target, as its skin (the outer shell) and the flesh (the inner parts) exhibit the appropriate properties $[11,12]$. The pumpkin had a mass of $4.2 \mathrm{~kg}$, an approximate diameter of $28 \mathrm{~cm}$ and a height of $19 \mathrm{~cm}$. The spring and the rod were the same as in the previous experiments; the speed of the radiosonde was the same and the distance was also the same. The same analyzes were made as by the previously shown experiment. The experiment was recorded and the video was uploaded to YouTube [13]. Fig. 14 shows a frame from the recording. After the collision, the radiosonde bounced back, as seen in Fig. 14. 


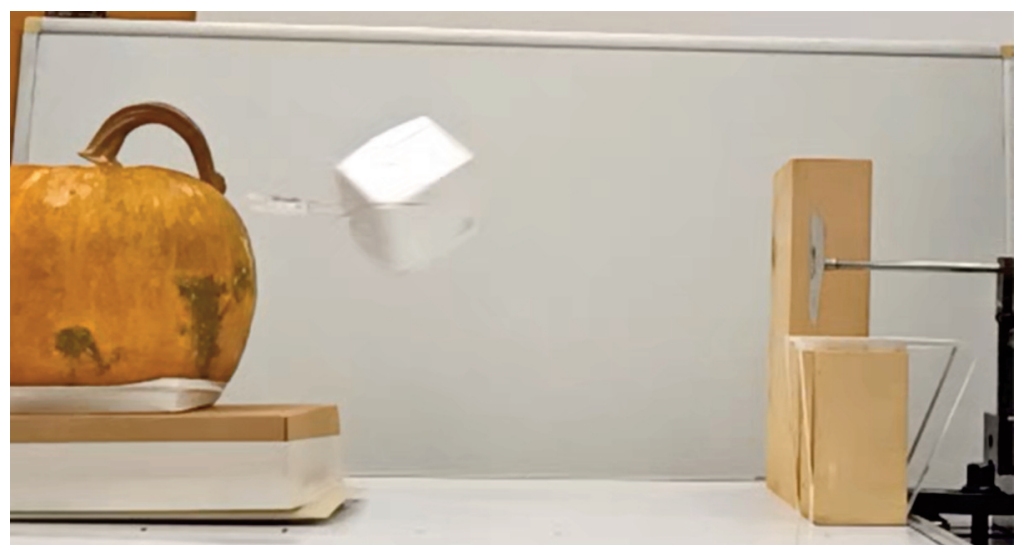

Fig. 14. Collison test after cracking, breaking and bouncing back.

The collision caused the stem of the pumpkin to break, and also produced a $55 \mathrm{~mm}$ long crack, as shown in Fig. 15. As seen in Fig. 13. the radiosonde partially broke apart as a result of the collision test.
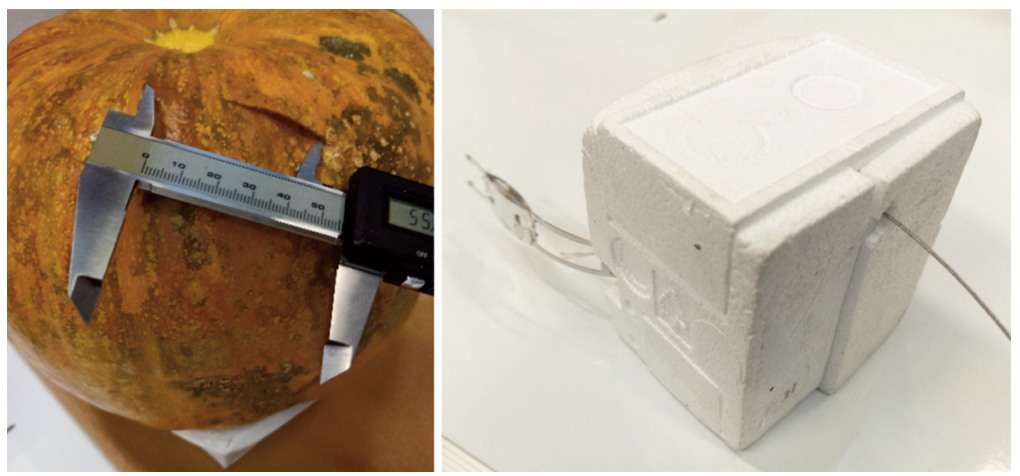

Fig. 15. Resulting crack on the pumpkin and damaged radiosonde.

\section{CONCLUSIONS}

The radiosondes that are used as the meteorological probes of sounding balloons are manufactured in numerous designs by numerous companies, making choosing between them difficult. This study first analyzed the structural properties of a selected set of four radiosondes, produced by three different companies, so as to rank them in terms of their estimated damage-causing potential in possible collisions.

One specific factor to be considered in this regard is area density. As the measurements and analysis reported in this paper show, radiosondes classified as having light-weight status may nevertheless exhibit different area densities. A larger area density, in turn, can lead to greater forces in case of a collision. The hardness, deformability of radiosonde parts can also give rise to negative, damage-causing properties. The properties of the devices as whole units can be also different.

Our ranking of the four devices considered - the Graw DFM-09, the Vaisala RS41, the Vaisala RS92, and Meteomodem M10 - in terms of their structural properties which bear upon their damage-causing potential showed that the most harmful of the four devices, in the event of a possible collision, would be the Vaisala RS-92SGPA, while the least harmful would be the Meteomodem M10. 
Next, we used the potentially least damage-causing probe so identified (the Meteomodem M10) in experimental collision tests with a heavy target and with a pumpkin model, in order to evaluate the possible damage caused by and to the radiosonde in different types of collisions. These tests lead us to conclude that, at the minimal descending speed in the case of a bad parachute (or no parachute) of $10 \mathrm{~m} / \mathrm{s}$, such radiosondes may indeed be significantly harmed and in colliding with a hard object. Our experiments also showed that the M10 radiosonde could cause significant damage to softer obstacles in such a collision, while itself partially disintegrating. Despite being estimated to be the least dangerous of the four devices tested, therefore, the M10 radiosonde nevertheless still showed considerable potential for causing damage, and to be damaged, if involved in collisions with hard or soft objects.

\section{REFERENCES}

[1] Nash, J., 2015, "Measurement of upper-air pressure, temperature and humidity; Instruments and Observing Methods Report No. 121," World Meteorological Organization, 20.03.2020. https://library.wmo.int/doc num.php?explnum id=7366.

[2] (EU) No 923/2012 EUR-Lex, Commission implementing regulation (EU) No. 923/2012, https://eur-lex.europa.eu/legal-content/EN/TXT/PDF/?uri=CELEX:32012R0923\&from=EN.

[3] YXLON CT Modular, 10.10.2019. https://www.yxlon.com/en/products/x-ray-and-ct-inspectionsystems/customized-solutions.

[4] GOM Triple Scan, 02.05.2020. https://www.gom.com/metrology-systems/atos/atos-triplescan.html.

[5] GOM Inspect, 02.05.2020. https://www.gom.com/3d-software/gom-inspect-suite.html.

[6] Szalai, Sz. and Czinege, I., 2017, "Digital Image Analysis of Sheet Metal Testing and Forming," In: 15th IMEKO TC10 Workshop on Technical Diagnostics in Cyber-Physical Era, edited by Viharos, Zs. J., Budapest, Hungary, International Measurement Confederation (IMEKO), pp. 176-180.

[7] Graw, DFM-09 Data Sheet V01.13; 04.06.2020. https://www.graw.de/fileadmin/cms upload/en/Resources/.pdf

[8] Vaisala, Radiosonde RS41-SG; 04.06.2020. https://www.vaisala.com/sites/default/files/documents/RS41-SG-Datasheet-B211321EN.pdf

[9] Vaisala, Radiosonde RS92-SGP; 04.06.2020. https:/www.vaisala.com/sites/default/files/documents/RS92SGP-Datasheet-B210358EN-FLOW.pdf

[10] Meteomodem, Radiosonde M10, 04.06.2020. http://www.meteomodem.com/docs/en/Leaflet$\underline{\text { m10.pdf }}$

[11] Mayor, L., Cunha, R.L., and Sereno, A.M., 2007, "Relation between mechanical properties and structural changes during osmotic dehydration of pumpkin", Food Research International, 40(4), pp. 448-460, https://doi.org/10.1016/j.foodres.2007.02.004.

[12] Emadi, B., Kosse, V. and Yarlagadda P. KOV, 2005, "Mechanical Properties of Pumpkin", International Journal of Food Properties, 8(2), pp. 277-287, https://doi.org/10.1081/JFP200063044.

[13] Video by Hegyi, N., "Collision test of a radiosonde with a pumpkin," 21.12.2020. https://youtu.be/mBRFio $1 \mathrm{kCMg}$ 


\title{
PORÓWNAWCZA ANALIZA STRUKTURALNA CZTERECH MODELI RADIOSOND
}

\begin{abstract}
Abstrakt
W pracy przeprowadzono kompleksową analizę strukturalną czterech modeli radiosond (urządzeń stosowanych przy balonach meteorologicznych) produkowanych przez trzy różne firmy: Graw, Vaisala i Meteomodem. Radiosondy rozłożono na części w celu dokonania oględzin i pomiarów ręcznych, wykonano trójwymiarowe zdjęcia tomograficzne ich wewnętrznej struktury oraz zeskanowano ich zewnętrzne kształty za pomocą trójwymiarowego skanera. Po porównaniu właściwości strukturalnych radiosond, model Meteomodem M10 został uznany za najmniej szkodliwy w potencjalnym zderzeniu z przeszkodą. Następnie przeprowadzono testy zderzeniowe radiosondy Meteomodem M10 z przeszkodą twardą oraz miękką w celu oceny możliwych uszkodzeń w różnych typach kolizji.
\end{abstract}

Słowa kluczowe: radiosonda, balon wolny bezzałogowy, tomografia komputerowa, test zderzeniowy 